\title{
Thrombolytic Therapy for Stroke in Turkey: Meta-analysis of Published Case Series
}

\author{
İnmede Trombolitik Tedavi: Türkiye'den Basılmış Çalışmaların Meta-Analizi
}

\author{
(1) Mustafa Çetiner ${ }^{1}$, (1) Ethem Murat Arsava², (® Mehmet Akif Topçuoğlu2 \\ ${ }^{1}$ Kutahya University of Health Sciences Faculty of Medicine, Department of Neurology, Kutahya, Turkey \\ 2Hacettepe University Faculty of Medicine, Department of Neurology, Ankara, Turkey
}

\begin{abstract}
Objective: To evaluate the results of published case series originating from Turkey, which may be useful for system planning and institutional goal setting in the clinical practice of intravenous tissue plasminogen activator therapy for acute stroke.

Materials and Methods: A meta-analysis of case series, published in the last 10 years, from Turkish hospitals / institutions about intravenous thrombolytic therapy in acute stroke was performed. Weighted averages and $95 \%$ confidence intervals, Q and $\mathrm{I}^{2}$ values were calculated using the standard method based on random-effect model.

Results: A total of 2349 patients ( $52 \%$ female, mean age $65 \pm 12$ years) in 21 articles were included. The mean symptom-to-needle time was $111 \pm 16$ minutes; pre-thrombolysis average NIH stroke score was 13.8 4 4.2; mean good prognosis (modified Rankin's score, 2 or lower) rate was $59.6 \%$; mortality rate was $16.5 \%$, and symptomatic thrombolytic-related intracerebral bleeding was $5.6 \%$. There was no large grade heterogeneity among the enrolled series.

Conclusion: Results of published Turkey-based thrombolysis case series meet the current world standards. The values produced herein can be used as standards for center-based quality metrics.
\end{abstract}

Keywords: tPA, alteplase, plasminogen, stroke unit, intracerebral hemorrhage, acute stroke

Öz

Amaç: Akut inme klinik pratiğinde intravenöz doku plazminojen aktivatörü kullanımına dair ülkemiz kaynaklı olgu serilerinin sonuçlarının değerlendirilmesi sistem planlaması ve hedef belirleme açısından faydalı olabilir.

Gereç ve Yöntem: Akut inmede intravenöz trombolitik tedavi uygulamaları ile ilgili son 10 yıl içinde yayınlanmış Türkiye adresli olgu serilerinin meta-analizi yapılmıştır. Random-effect model temelli standart yöntem ile ağırlıklı ortalama ve \%95 güven aralıkları, Q ve $\mathrm{I}^{2}$ değerleri hesaplanmıştır.

Bulgular: Toplam 21 makaledeki 2349 olgu (\%52 kadın, yaş $65 \pm 12$ yıl) incelenmiştir. Ortalama semptom-iğne zamanı $111 \pm 16$ dakika; NIH inme ölçeği skoru $13,8 \pm 4,2$; takip iyi prognoz (Modifiye Rankin skoru $\leq 2$ ) \%59,6; mortalite $\% 16,5$ ve semptomatik trombolitik ilişkili kanama $\% 5,6$ 'dır. Seriler arasında yüksek dereceli heterojenite olmadığ 1 görülmüştür.

Sonuç: Türkiye kaynaklı trombolitik olgu serilerinde yayınlanmış sonuçlar güncel dünya standartlarını karşılamaktadır. Bu değerler merkezlerce kalite metrikleri için standart olarak kullanılabilir.

Anahtar Kelimeler: tPA, alteplaz, plazminojen, inme ünitesi, intraserebral kanama, akut inme

\section{Introduction}

Thrombolytic therapy with intravenous (IV) tissue plasminogen activator (tPA) is a clinically useful standard in acute ischemic stroke. Although the positive effect of IV tPA has been demonstrated in many randomized controlled trials, practices in countries are heterogeneous (1). Therefore, practices are evaluated with prospective data banks, combined analysis of hospital series or metrics held by health care practitioners. The aim of this study was to evaluate IV tPA use in acute stroke clinical practice by performing a meta-analysis of single or multicenter case series and presentations published in our country.

\footnotetext{
Address for Correspondence/Yazışma Adresi: Mehmet Akif Topçuoğlu MD, Hacettepe University Faculty of Medicine, Department of Neurology, Ankara, Turkey Phone: +90 3123051809 E-mail: mat@ hacettepe.edu.tr ORCID: orcid.org/0000-0002-7267-1431 Received/Gelis Tarihi: 06.08.2019 Accepted/Kabul Tarihi: 23.01.2020

${ }^{\circ}$ Copyright 2020 by Turkish Neurological Society

Turkish Journal of Neurology published by Galenos Publishing House.
} 


\section{Materials and Methods}

In this study, the manual " Preferred Reporting Items for Systematic Reviews and Meta-analyses” (2) was followed. The literature survey was conducted "online" in PubMed, Google Scholar, SCOPUS, Web of Science and Turk Medline data banks in July 2019. In addition, resource lists of articles found relevant were also reviewed in terms of potential additional articles. "Turkey" and "thrombolysis" or "thrombolytic" and "stroke" were used as combinations of keywords in scans in English; whereas "Turkiye" or "Türkiye" and "tromboliz" or "trombolitik" and "inme" were used in scans in Turkish.

\section{Study Selection and Criteria Investigated}

Age, sex, symptom-to-needle time, frequency of stroke risk factors (hypertension, diabetes, atrial fibrillation), pre-treatment National Institutes of Health stroke scale (NIHSS) score and posttreatment NIHSS score at the $24^{\text {th }}$ hour were the main defining metrics searched in the studies. The outcome parameters were functional status, mortality, and symptomatic bleeding rates associated with tPA. The scores " $0-1$ " or " $0-2$ " of the modified Rankin scale for functional status reflected "good prognosis" as specified. Discharge, third month and even though an unspecified time interval were matched in this analysis for the outcome determination time. The data were collected separately by two researchers (MC and MAT). The critical data of prognostic criteria in the articles were the modified Rankin scale, mortality, and symptomatic bleeding; if one of these was presented objectively, the study was included in the analysis.

\section{Statistical Analysis}

If the data were given as a percentage, they were translated into numbers and weighted values were calculated and added to the overall averages. Values are expressed as mean \pm standard deviation (SD) or mean [95\% confidence interval (CI)]. For calculations, the SPSS ${ }^{\circledR}$ version 22 package program and an addition of Microsoft Office Excel ${ }^{\circledR}$ made by Neyeloff et al. (3) were used. The randomeffect model was used for meta-analysis. Heterogeneity between studies was evaluated using thee $\mathrm{Q}$ test and $\mathrm{I}^{2}$ calculation. However, $\mathrm{Q}_{\mathrm{v}}$ and $\mathrm{I}_{\mathrm{v}}{ }^{2}$ values were calculated to represent each study's weight in the model because of the assumption that variability would be due to sample error and variability, and variability in the population.

\section{Results}

\section{Study Selection and Patients}

Two hundred articles were identified in PubMed, 6020 (first 500) in Google Scholar, 97 in Scopus, 131 in Web of Science and 37 in Turk Medline. The title and later summary of 19, 33, 17, 21 , and 33 articles, respectively, were found to be related with the topic. After the same articles were sorted in Endnote and then removed, the full texts of the remaining 54 articles were reviewed. Articles where the same data were repeated (according to the time interval), articles that did not contain critical data, and articles whose content was found to be related to different topics were removed. Ultimately, 21 articles were included in this analysis (426). The total number of patients was 2349 , of which $48 \%$ came from the Turkish National IV Thrombolysis Registry trial (15).
Five case reports in four articles were included in the analysis. The average number of patients in other articles was 70 (12-319).

Of the patients analyzed, 1221 (52\%) were female and $1128(48 \%)$ were male, with an average age of $65 \pm 12$ years. Symptom-to-needle time was specified for 1735 (74\%) patients in 15 studies, with an average of $111 \pm 16$ minutes $(4,5,6,7,8,11$ $15,17,18,20,21,24,25)$. Vascular risk factors were determined in $908(39 \%)$ patients in 11 studies, and the frequency of hypertension was $65 \%$, diabetes was $38 \%$, atrial fibrillation was $31 \%$, and hyperlipidemia was $34 \%(6,11,13,14,16,17,19,20$, $21,24,26)$. The NIHSS score at arrival was given in 20 studies $(\mathrm{n}=2263,96 \%)$. The NIHSS score was specified as mean \pm SD in 1834 patients, mean (maximum-minimum) in 319 patients, and median in 105 patients, with a mean of $13.8 \pm 4.2(4-21,24,25,26)$. The NIHSS score 24 hours after IV tPA was reported in 16 studies $(\mathrm{n}=744,32 \%)$. It was specified as mean $\pm \mathrm{SD}$ in 569 patients, mean (maximum-minimum) in 137 patients, median in 105 patients, and mean in 33 patients. The mean score was $9.1 \pm 2.8$ $(4,5,8-14,17,18,21,24,26)$.

\section{Good Prognosis}

Apart from two studies, follow-up modified Rankin scale scores were present and 1298 of 2179 patients (59.6\%; 95\% CI: $38.1 \%$ - $80.1 \%$ ) showed good functional outcome with IV tPA (modified Rankin scale score at most 2) $(4-12,14,15,18,19,20,22,25,26)$. The mean and $95 \% \mathrm{CI}$ distribution of the series are given in Figure 1A. Heterogeneity was of a mild degree $\left(Q_{v} 10.3258\right.$ and $\left.\mathrm{I}_{\mathrm{v}}^{2} 12.84\right)$.

\section{Mortality}

Nineteen studies had mortality data $(4-21,24,26)$. Of the 2122 patients included in these, 350 patients died $(16.5 \%, 95 \% \mathrm{CI}$ : 2.3-30.7\%). Studies were found to show significant heterogeneity, which was at acceptable levels $\left(Q_{v} 14.6217\right.$ and $I_{v}^{2}$ 38.4). The individual mean and $95 \% \mathrm{CI}$ of the series are given in Figure 1B.

\section{Cerebral Hemorrhage Due to Thrombolytic Treatment}

In the 20 studies, symptomatic cerebral hemorrhagic transformation / bleeding rates were given $(4-25,27)$. Of the 2249 patients included in these studies, symptomatic bleeding was detected in 132 patients and its frequency was 5.6\% (95\% CI: $-0.7 \%-12.4 \%)$. The heterogeneity between the series was low $\left(Q_{v}\right.$ $\left.10.4942 ; \mathrm{I}_{\mathrm{v}}{ }^{2} 14.24\right)$. The frequency of bleeding in the series is shown in Figure 1C.

\section{Discussion}

With this meta-analysis, the current status of acute stroke thrombolysis administrations in our country has been evaluated. It has been updated with twice as many cases as the previously published Turkish National IV Thrombolysis Registry trial (15). The rate of good prognosis (modified Rankin scale score 0-2) with IV tPA was approximately $60 \%$ in the case series published in our country. At this point, this rate is likely to rise, considering that most patients were evaluated on discharge from hospital or within less than three months, not at the third month (the rate of thirdmonth results was $60 \%$ in the Turkish National IV Thrombolysis Registry Trial). This benefit rate fits with the conclusion that "disability is prevented by IV tPA in the one-half-to-two-thirds 


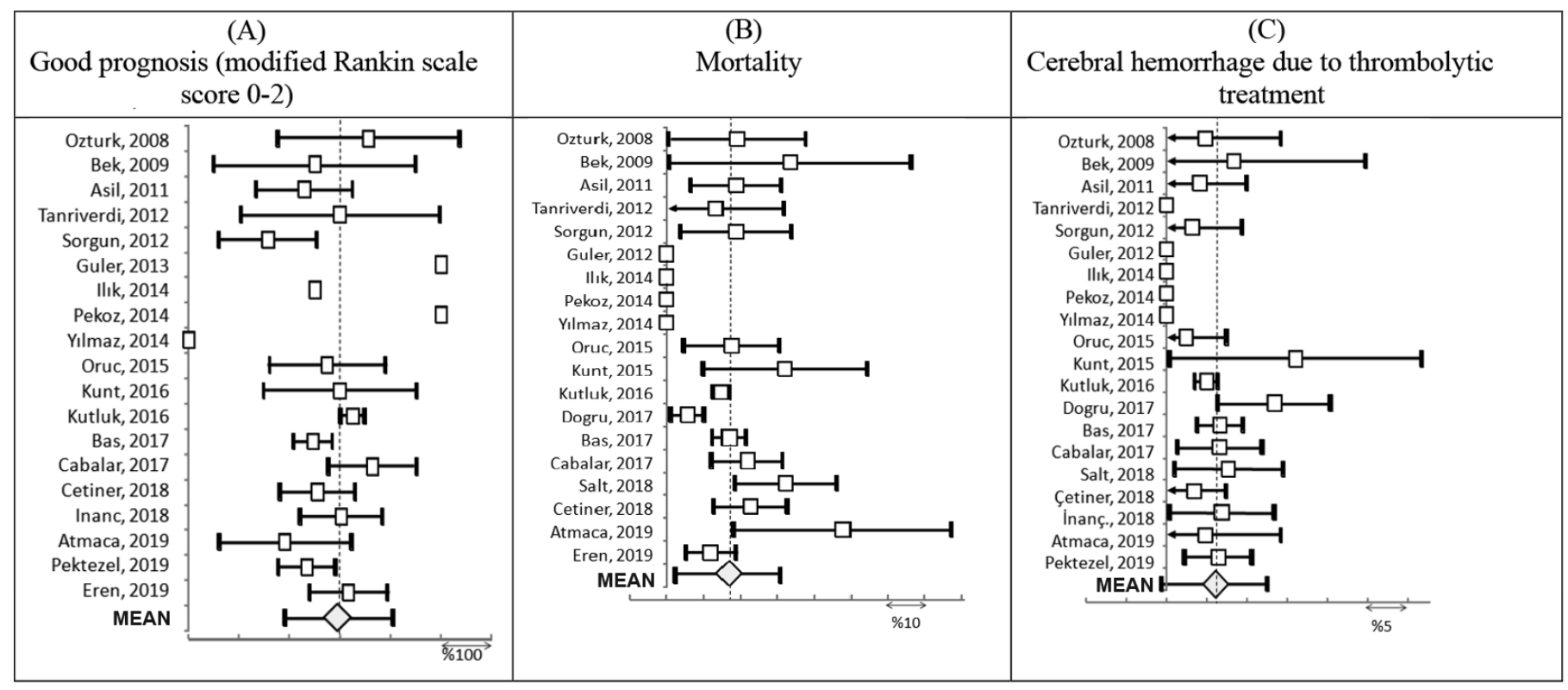

Figure 1. Graphs express percentage, mean, and 95\% confidence intervals

portion of patients" coming from randomized controlled trials (28), and large patient repositories such as Safe Implementation of Treatments in stroke International (29). IV tPA administrations in our country obviously result in this level or even higher rates of benefit.

The mortality rate in patients with acute stroke who were treated with IV tPA was $16.5 \%$ in our analysis, which was within the $15-25 \%$ range expressed by the results of the Turkish National IV Thrombolysis Registry Trial (15), the NINDS rtPA Trial (28), which revealed the beneficial effect of IV tPA for the first time, and the current meta-analyses (30).

The symptomatic bleeding complication rate due to IV tPA was $5.6 \%$ in this meta-analysis, and was within the frequency range reported by randomized controlled studies and developed countries $(15,28,29,30)$. That is, IV tPA can be safely implemented in our country.

Another result that stood out in this analysis was that the most basic metrics, such as the NIHSS score at arrival and in the post-treatment period, hospitalization time, modified Rankin scale score distribution at discharge (a percentage bar graph was only available in one study), were not given in many studies. It is therefore considered necessary to promote both the publication of data and the regular and objective collection of basic quality metrics.

IV tPA has comprehensively changed the clinical practice of acute stroke. The systemic transformation it has caused has provided an improvement that far exceeds the pharmacologic beneficial effects of the drug, and has enabled other treatment methods to be used. However, in the context of acute stroke diagnosis and treatment, the success of any system can only be achieved through good monitoring. This is possible by objective and open data collection. Systematic reviews and analyses also serve this purpose.

\section{Conclusion}

The published results of IV tPA case series from Turkey meet current world standards. These values can be used as standards in quality metrics by centers.

Ethics

Ethics Committee Approval: Ethics committee approval is not required, as it is meta-analysis.

Informed Consent: Patient approval is not required, as it is meta-analysis.

Peer-review: Externally and internally peer-reviewed.

\section{Authorship Contributions}

Concept: M.Ç., E.M.A., M.A.T., Design: M.Ç., E.M.A., M.A.T., Data Collection or Processing: M.Ç., E.M.A., M.A.T., Analysis or Interpretation: M.Ç., E.M.A., M.A.T., Literature Search: M.Ç., E.M.A., M.A.T., Writing: M.A.T.

Conflict of Interest: No conflict of interest was declared by the authors.

Financial Disclosure: The authors declared that this study received no financial support.

\section{References}

1. Aguiar de Sousa D, von Martial R, Abilleira S, et al. Access to and delivery of acute ischaemic stroke treatments: A survey of national scientific societies and stroke experts in 44 European countries. Eur Stroke J 2019;4:13-28.

2. Moher D, Shamseer L, Clarke M, et al. Preferred reporting items for systematic review and meta-analysis protocols (PRISMA-P) 2015 statement. Syst Rev 2015;4:1

3. Neyeloff JL, Fuchs SC, Moreira LB. Meta-analyses and Forest plots using a microsoft excel spread sheet: step-by-step guide focusing on descriptive data analysis. BMC Res Notes 2012;5:52.

4. Ozturk V, Yaka E, Ugurel B, Poyraz T, Men S, Kutluk K. Intravenous Thrombolysis in Acute Ischemic Stroke: Experiences in Dokuz Eylül 
University Hospital, Medical Faculty, Department of Neurology. Journal of Neurological Sciences [Turkish] 2008;25:75-83.

5. Bek S KT, Genç G, Akgün H, Demirkaya Ş, Odabaşı Z. Akut iskemik inmede intravenöz trombolitik tedavi. Turk Norol Derg 2009;15:174180.

6. Asil T, Balci K, Utku U, İr N. Intravenous tPA Administration in Patients With Acute Ischemic Stroke: Edirne Experience. JNS 2011;28:317-321.

7. Tanrıverdi Z, Necioğlu-Örken D, Aksoy S, et al. Akut iskemik inmede intravenöz trombolitik tedavi: Şişli Etfal Eğitim ve Araştırma Hastanesi Nöroloji Kliniği deneyimi. Şişli Etfal Hastanesi Tip Bülteni 2012;46:165169.

8. Sorgun M, Togay-Işıkay C. Akut İskemik İnmede İntravenöz Trombolitik Tedavi. Ankara Üniversitesi Tip Fakültesi Mecmuası 2012;65:103-106.

9. Güler S, Utku U, Tuncel S, Çelik Y. Trombolitik tedaviden belirgin fayda göre karotis diseksiyon olgusu. Türk Beyin Damar Hast Der 2013;19:29-32.

10. İlik F, Pazarlı AC. İlçe Devlet Hastanesinde Trombolitik Tedavi Deneyimi: İki Olgu Sunumu. Turkiye Klinikleri J Neur 2014;9:123-126.

11. Peköz MT, Bıçakcı Ş, Özturk İ, Aslan K, Bozdemir H, Koç F. Fibromuscular Dysplasia and Intravenous Thrombolytic Treatment. Archives of Neuropsychiatry 2014;51:175-177.

12. Yılmaz A, Güngör L. Akut İnme İçin Ambulansta Trombolitik Tedavi Uygulamas1. Turkiye Klinikleri J Neur 2014;9:85-90.

13. Oruç S DH, Yaman M, Yılmaz Küsbeci Ö, Akpınar Oruç O, Tünay K, Günebakan C. Akut iskemik inmeli olgularda Kocatepe Üniversitesi Nöroloji Kliniği'nin intravenöz trombolitik tedavi deneyimleri. Türk Beyin Damar Hast Der 2015;21:189-193.

14. Kunt R. Bir devlet hastanesi bakı̧̧ açısıyla akut iskemik inmede intravenöz trombolitik tedavi. Türk Beyin Damar Hast Der 2016;22:91-99.

15. Kutluk K, Kaya D, Afsar N, et al. Analyses of the Turkish National Intravenous Thrombolysis Registry. J Stroke Cerebrovasc Dis 2016;25:10411047.

16. Doğru Y. Trombolitik tedavide erken dönem prognoz ve kanama açısından risk faktörlerinin değerlendirilmesi (uzmanlık tezi). Edirne: Trakya Üniversitesi; 2017.

17. Cetiner M, Aydin HE, Guler M, Canbaz-Kabay S, Zorlu Y. Predictive Factors for Functional Outcomes After Intravenous Thrombolytic Therapy in Acute Ischemic Stroke. Clin Appl Thromb Hemost 2018;24:171-177.
18. Çetiner M, Canbaz Kabay S, Aydın H. Akut İskemik İnmede İntravenöz Trombolitik Tedavi: Kütahya Deneyimleri. Turk J Neurol 2017;23:193198.

19. Bas DF, Ozdemir AO. The effect of metabolic syndrome and obesity on outcomes of acute ischemic stroke patients treated with systemic thrombolysis. J Neurol Sci 2017;383:1-4.

20. Çabalar Murat, Taşdemir N, Erdogan HA, et al. Our experiences of intravenous thrombolytic treatment in acute ischemic stroke. Bakırköy Tip Dergisi 2018;14:71-75.

21. Salt O, Baykan N, Kaymaz ND, et al. Evaluation of Patients with Ischemic Stroke Receiving IV t-PA in the Emergency Department. Eurasian J Emerg Med 2018;17 50-54.

22. İnanç Y, Giray S, İnanç Y. Mean Platelet Volume, C-Reactive Protein, and Prognosis in Patients with Acute Ischemic Stroke Following Intravenous Thrombolytic Treatment. Med Sci Monit 2018;24:3782-3788.

23. İnanç Y AZ, Giray S, İnanç Y. Demographic characteristics of patients who recovered or worsened after intravenous thrombolysis within 24 hours of acute ischemic stroke. Neurol Sci Neurophysiol 2018;35:29-33.

24. Atmaca M, Kocatürk O, Marufoğlu F, et al. Experience of Intravenous Thrombolytic Treatment in Sanliurfa: A Prospective Study. Turk J Neurol 2019;25:19-25.

25. Pektezel MY, Yilmaz E, Arsava EM, Topcuoglu MA. Neutrophil-toLymphocyte Ratio and Response to Intravenous Thrombolysis in Patients with Acute Ischemic Stroke. J Stroke Cerebrovasc Dis 2019;28:1853-1859.

26. Eren F YA, Öngün G, Turan Işsk M, Öztürk Ş. The prognostic value of hematological and biochemical parameters in ischemic stroke patients treated with thrombolytic therapy. Pam Med J 2019:235-241.

27. Eryıldız Sezer E, Özdemir A. Akut İskemik İnmede İntravenöz Trombolitik Tedavi Sonrası Erken Dönem Tam İyileşme ile İlişkili Faktörler. Arch Neuropsychiatry 2018;55:80-83.

28. NationalInstitute of Neurological D, Strokert PASSG. Tissue plasminogen activator for acute ischemic stroke. N Engl J Med 1995;333:1581-1587.

29. Wahlgren N, Ahmed N, Davalos A, et al. Thrombolysis with alteplase for acute ischaemic stroke in the Safe Implementation of Thrombolysis in Stroke-Monitoring Study (SITS-MOST): an observational study. Lancet 2007;369:275-282.

30. Wardlaw JM, Murray V, Berge E, del Zoppo GJ. Thrombolysis for acute ischaemic stroke. Cochrane Database SystRev 2014;2014:CD000213. 